\title{
Personalitas Perusahaan Multinasional Dalam Hukum Internasional
}

\author{
Syukri*; Retno Kusniati \\ Fakultas Hukum Universitas Jambi \\ *Coresponding author: syukri@lkpp.go.id
}

$\begin{array}{ll}\text { Submission } & : \text { 20 Januari } 2020 \\ \text { Revision } & : \text { 04 Februari } 2020 \\ \text { Publication } & : 11 \text { Februari 2020 } \\ \text { DOI } & : \text { doi.org/10.36565/up.v1i1.8572 }\end{array}$

\begin{abstract}
This paper aims to find out and analyze the personality and responsibilities of multinational cooperation in international law. The type of research is normative studies by using statutory, conceptual and historical approaches. It is shown that the personality of multinational cooperation in international law is limited as a quasi subject of international law, which is applied in the context of: 1) party in the settlement of international disputes, limited to the cases of investment disputes through, international arbitration; and 2) party inthe drafting of investment contracts using the principles of international trade law, in particular the principles of National Treatment and Most Favored Nations. The responsibilitiesof multinational cooperation in international law are based on soft law provisions yet applied through host country as the intermediary actor by the regulation in national legal provisions.
\end{abstract}

\section{Keyword: International Legal Personality; Multinational Cooperation.}

\begin{abstract}
Abstrak
Tulisan ini bertujuan untuk mengetahui dan menganalisis personalitas dan tanggung jawab perusahaan multinasional dalam hukum internasional. Metode Penelitian yang digunakan adalah penelitian normatif dengan pendekatan perundang-undangan, pendekatan konseptual dan pendekatan historis. Hasil dari
\end{abstract}



penelitian ini menunjukkan bahwa personalitas perusahaan multinasional dalam hukum terbatas sebagai quasi subjek hukum internasional yang diwujudkan dengan: 1) Dapat menjadi pihak dalam penyelesaian sengketa internasional terbatas kasus sengketa penanaman modal melalui arbitrase internasional; dan 2) Membuat kontrak penanaman modal menggunakan prinsip-prinsip hukum perdagangan internasional khususnya prinsip National Treatment dan Most Favoured Nations.Tanggung jawab dalam hukum internasional berdasarkan ketentuan yang bersifat soft law namun diterapkan melalui perantara negara tuan rumah dengan mengaturnya dalam aturan hukum nasional.

\section{Kata Kunci: Personalitas Hukum Internasional; Perusahaan Multinasional.}

\section{A. Pendahuluan}

Perusahaan multinasional paling banyak dibicarakan karena merupakan asosiasi bisnis dalam rangka globalisasi dunia dan ekonomi. ${ }^{1}$ Perusahaan multinasional sebagai organisasi bisnis swasta terdiri atas beberapa badan hukum yang terhubung oleh perusahaan induk dan dibedakan berdasarkan ukuran dan penyebaran multinasionalnya. ${ }^{2}$ Bentuk pengaruh perusahaan multinasional terutama modal yang dimilikinya dan pengaruh luas teritorial karena memiliki cabang diberbagai negara. ${ }^{3}$ Dengan kekuatan modal, teknologi dan sistem manajemen yang baik, perusahaan multinasional mengontrol aliran modal, teknologi dan distribusi barang melintasi batas-batas negara.

An An Chandrawulan. Hukum Perusahaan Multinasional Keni Media, Bandung. 2014. hal. 1.

2 Shaw N Malcom, Hukum Internasional (International Law) diterjemahkan oleh Derta Sri Widowatie. Imam Baehaqi dan M. Khozim. Nusa Media, Bandung. 2013. hal. 228.

3 Boer Mauna. Hukum Internasional Pengertian, Peran dan Fungsi dalam Dinamika Global. Alumni. Bandung. 2011. hal. 716. 
Karakter perusahaan multinasional juga adalah kemampuan untuk mengkoordinasikan antara perusahaanperusahaan di lebih satu negara. ${ }^{4}$ Induk perusahaan menjadi pimpinan sentral yang mengendalikan dan mengoordinasikan anak-anak perusahaan dalam satu kesatuan ekonomi, ${ }^{5}$ sedangkan anak perusahaan sebagai kepanjangan tangan dari induk perusahaan dalam pengoperasian aktivitasnya. ${ }^{6}$ Dengan karakter yang melintasi batas negara antara induk perusahaan dan anak perusahaan akan menjadi pembeda dengan perusahaan domestik multi lokasi yang pengoperasian kegiatan usahanya berada di satu negara. ${ }^{7}$

Perusahaan multinasional sebagai suatu perusahaan yang memiliki, mengawasi dan mengatur aktivitas usahanya di lebih dari satu negara dilakukan dan dibiayai dengan penanaman modal asing langsung (Foreign Direct Investment) ${ }^{8}$ "Penanaman modal asing merupakan aktivitas perusahaan yang memberikan status multinasional bagi perusahaanperusahaan tertentu,"9 atau dengan kata lain bahwa suatu perusahaan dapat dikatakan perusahaan multinasional jika perusahaan tersebut melakukan penanaman modal di negara lain.

Dalam aktivitas penanaman modal asing, perusahaan multinasional harus tunduk kepada Trade Related Investment Measures yang merupakan kerangka aturan Organisasi Perdagangan Dunia (World Trade Organization). Hasil dari perjanjian ini merupakan penegasan kembali prinsip-prinsip

4 An An Chandrawulan. Hukum Perusahaan Multinasional, Liberalisasi Hukum Perdagangan Internasional dan Hukum Penanaman Modal. Alumni. Bandung. 2011. hal. 155.

5 Sulistiowati, Tanggung Jawab Hukum pada Perusahaan Grup di Indonesia. Erlangga. Jakarta. 2013. hal. 23.

6 An an Chandrawulan. Op. Cit.. hal. 185.

7 An an Chandrawulan. Op. Cit., hal. 7.

8 Ibid., hal. 65

9 Ibid., hal. 68

Uti Possidetis: Journal of International Law, Vol. 1, No. 1 (2020) 
perdagangan internasional, yaitu prinsip National Treatment (Pasal III TRIMs), larangan penggunaan restriksi kuantitatif atau penggunaan kuota (Pasal XI TRIMs) dan tetap diberlakukannya ketentuan Most Favoured Nations dalam aturan General Agreement on Tariffs and Trade (Pasal III GATT). Teks perjanjian Trade Related Investment Measures memuat upaya-upaya penanaman modal yang dilarang, jangka waktu untuk negara-negara anggota untuk menghapus praktek-praktek yang dilarang dan mengakomodasi kepentingan negara berkembang dalam hal diperbolehkannya untuk tidak menerapkan ketentuan perjanjian tersebut sementara waktu. ${ }^{10}$

Aktivitas penenaman modal di Negara-negara berkembang tidak dapat dihindari karena kebutuhan terhadap penanaman modal asing karena faktor pesatnya pertumbuhan ekonomi dan persaingan perdagangan internasional. Berkaitan hal ini, Ida Bagus Wiyasa Putra menyatakan bahwa:

Kebutuhan terhadap modal asing merupakan kebutuhan yang tidak dapat dihindari oleh negara-negara berkembang, pertama, karena mutlaknya arti penting pembangunan ekonomi bagi negara-negara berkembang; Kedua, terbatasnya modal, informasi, manajemen, keahlian dan teknologi untuk mengubah sumber daya ekonomi potensial menjadi sumber daya ekonomi produktif.11

Fenomena semacam ini menimbulkan perilaku yang dikenal sebagai race to the bottom, yaitu "keadaan dimana negara-negara berkembang mengundang perusahaan multinasional untuk melakukan foreign direct investment

10 Huala Adolf, Perjanjian Penanaman Modal dalam Hukum Perdagangan Internasional (WTO). Cet. 2. Keni Media. Bandung. 2010. hal. 87.

11 Ida Bagus Wiyasa Putra. Aspek-Aspek Hukum Perdata Internasional dalam Transaksi Bisnis Internasional. Refika Aditama. Bandung. 2000. hal. 101. 
dengan cara berlomba memberikan kemudahan dan kelonggaran aturan hukum seringan mungkin dengan alasan untuk memacu pertumbuhan ekonominya". ${ }^{12}$

Keadaan dimana negara-negara mengundang perusahaan multinasional untuk melakukan penanaman modal mengakibatkan timbul posisi yang tidak seimbang antara perusahaan multinasional dan negara penerima investasi atau negara tuan rumah (host state). "Negara tuan rumah bukan hanya menjadi tidak mampu mencegah timbulnya pelanggaran hukum tapi justru turut melegalkan praktek-praktek pelanggaran hak-hak buruh, perusakan lingkungan dan pelanggaran hak konsumen yang dilakukan oleh perusahaan multinasional". ${ }^{13}$ Hal ini dikarenakan kekuatan modal yang dimiliki perusahaan multinasional mampu mempengaruhi perekonomian dan melakukan lobi politik dengan negara tuan rumah. Misalnya, pelanggaran hak asasi manusia berupa kekerasan dan "perusakan lingkungan di Papua (Irian Jaya) sebagai akibat dari pengoperasian proyek tembaga dan mas oleh PT Freeport Indonesia (suatu anak perusahaan Amerika Serikat, The Freeport-McMoran Company)". ${ }^{14}$

Dampak negatif lain dalam perekonomian negara penerima modal atau negara tuan rumah. Huala Adolf menambahkan bahwa:

“...Perusahaan multinasional banyak dikecam telah mengembalikan keuntungan-keuntungan dari kegiatan bisnisnya ke negara dimana perusahaan induknya berada. Dampak lainnya adalah penanaman modal asing oleh perusahaan multinasional dapat mendominasi

12 Iman Prihandono. Status dan Tanggung Jawab Multi-National Companies dalam Hukum Internasional" Global dan Strategis, Th. II. No.1, Januari-Juni 2008, hal. 71.

13 Ibid.

14 Huala Adolf. Perjanjian Penanaman Modal dalam Hukum Perdagangan Internasional (WTO). Op. Cit., hal. 6. 
perusahaan-perusahaan lokal. Sebagai akibatnya, mereka dapat mempengaruhi kebijakan-kebijakan ekonomi atau bahkan kebijakan politis dari negara penerima". ${ }^{15}$

Untuk memberikan pembatasan tanggung jawab kepada perusahaan multinasional terlebih dahulu melihat personalitas hukum (legal personality) dari perusahaan multinasional tersebut. "Personalitas hukum adalah yang menentukan hakhak dan kewajiban yang dimiliki subjek hukum".16 Secara yuridis perusahaan multinasional di abad ke-21 telah dipertimbangan menjadi seperti halnya manusia biasa mempunyai hak dan kewajiban (artifical person) yang diciptakan oleh hukum dan secara nyata mempunyai hak dalam proses hukum yang melampau garis suatu negara. ${ }^{17}$

Zakia Arifindalam Foreign Direct Investment and Sustainable Development in the Last sebagaimana dikutip Iman Prihandono dalam Status dan Tanggung Jawab Multi-National Companies dalam Hukum Internasional mengemukakan pendapatnya tentang personalitas hukum perusahaan multinasional bahwa:

Pada umumnya perusahaan multinasional dikategorikan sebagai badan hukum (legal person) yang mempunyai kedudukan sama dengan warga negara (natural person) di tempat perusahaan multinasional tersebut didirikan atau berdomisi usaha. Dengan demikian, dapat dikatakan bahwa saat ini negaralah satu satunya entitas yang mempunyai kewenangan mengatur dan mengontrol kegiatan perusahaan multinasional. ${ }^{18}$

Ibid.

16 Jawahir Tantowi dan Pranoto Iskandar. Hukum Internasional Kontemporer. Cet. 1. Refika Aditama. Bandung. 2006. hal. 104.

17 An an Chandrawulan. Hukum Perusahaan Multinasional, Liberalisasi Hukum Perdagangan Internasional dan Hukum Penanaman Modal. Op. Cit., hal. 180-181.

18 Iman Prihandono. Op. Cit., hal. 69.

Uti Possidetis: Journal of International Law, Vol. 1, No. 1 (2020) 
Penjelasan di atas menunjukkan bahwa personalitas hukum dari perusahaan multinasional terdiri dari induk perusahaan yang berada di negara asal (home state) dan anak perusahaan di negara tuan rumah (host state). Raymon Vernon dalam Sovereignty At Bay; The Multinational Spread of U.S Enterprise sebagaimana di kutip An An Chandrawulan dalam bukunya Hukum Perusahaan Multinasional mengemukakan keuntungan status hukum yang dimiliki perusahaan multinasional bahwa:

Perusahaan multinasional telah diberi keuntungan dengan diterapkannya status hukum atau hak hukum, perusahaan multinasional menikmati keuntungan dari adanya pengecualian dari beberapa karakteristik ketidak leluasaan manusia biasa. Misalnya, anak-anak perusahaan multinasional ini bebas atau dapat memiliki status hukum di beberapa negara di dunia. Perusahaan multinasional yang berkedudukan di AS misalnya, memiliki kebangsaan di Perancis, Brazil atau Togo. ${ }^{19}$

Dalam hukum internasional banyak terjadi perdebatan para ahli yang berujung pada belum adanya kesepakatan mengenai personalitas hukum internasional (international legal personality) dari perusahaan multinasional. Berkenaan dengan hal ini, Fotourus menyatakan bahwa: "...it is possible for the international legal process to acknowledge that TNEs (transnational enterprise) are significant actors in the world economy and thus to recognize that they have a degree of legal capacity in international $\operatorname{law}^{20}$ (Terjemahan bebas: Hal yang dimungkinkan untuk hukum internasional mengakui bahwa perusahaan multinasional merupakan aktor penting dalam perekonomian

19 An an Chandrawulan. Hukum Perusahaan Multinasional. Op. Cit., hal. 35 .

20 Ibid., hal. 34.

Uti Possidetis: Journal of International Law, Vol. 1, No. 1 (2020) 
dunia dan demikian untuk mengakui bahwa mereka memiliki gelar dalam kapasitas hukum dalam hukum internasional).

Sarjana lain yang mengemukakan pendapatnya mengenai personalitas hukum internasional (international legal personality) dari perusahaan multinasional adalah Malanczuk, bahwa:

“... Multinational companies are still formally not 'subject of international law' in any meaningful sense of the term, although there is limited recognition of their legal personality in certain dispute settlement mechanisms. Are such, their existence in barely recognized by general international law (in contrast to a few... special soft law instruments aiming at the regulation of their activities). ${ }^{21}$ (Terjemahan bebas: Perusahaan multinasional masih resmi tidak tunduk pada hukum internasional dalam arti yang bermakna istilah, meskipun ada pengakuan terbatas kepribadian hukum mereka dalam mekanisme penyelesaian sengketa tertentu).

Perdebatan mengenai personalitas perusahaan multinasional dalam hukum internasional tidaklah lantas mengabaikan realita bahwa eksistensinya yang diterima dalam masyarakat internasional. Perusahaan multinasional memainkan peranan penting dalam kehidupan global dan dapat melakukan kerjasama dan membuat persetujuan dengan pemerintah suatu negara dengan tidak diatur dengan ketentuan nasional suatu negara melainkan dengan memberlakukan prinsip-prinsip umum hukum internasional.

Hukum internasional juga telah mengakui bahwa negara memiliki hak untuk mengontrol perusahaan multinasional. ${ }^{22}$ "Semua benda yang ada di wilayah suatu negara tunduk pada kekuasaan dan hukum negara itu”. ${ }^{23}$ Pengaturan negara secara

\footnotetext{
Ibid.

Ibid., hal. 12.

23 Sugeng Istanto. Hukum Internasional. Cet. 2. Penerbitan Universitas Atma Jaya Yogyakarta. Yogyakarta. 1998. hal. 42
} 
nasional bertujuan "untuk menjamin agar keberadaan perusahaan multinasional dapat memberi keuntungan ekonomi dan sosial secara maksimal kepada perekonomian nasional". ${ }^{24}$ Sejalan dengan hal tersebut Jimly Asshiddiqie berpendapat bahwa:

“...Sistem perekonomian Indonesia bukan sistem kapitalisme, tetapi demokrasi ekonomi dan ekonomi pasar sosial demi mencapai kesejahteraan rakyat. Maka negara juga dapat melakukan pembatasan tertentu sebagai pelaksanaan konsep welfare state dan sistem perekonomian nasional berdasarkan UUD 1945.25

Meskipun demikian "beberapa ahli hukum internasional merasa bahwa ketergantungan pada hukum nasional sebuah negara untuk meminta pertanggungjawaban perusahaan multinasional saat ini dirasa tidak cukup". ${ }^{26}$ Oleh karena itu perusahaan multinasional harus dibebankan tanggung jawab secara internasional dengan tidak mengenyampingkan aturan negara tuan rumah.

Nancy L Mensch dalam Codes, Lawsuits or International Law: How Should the Multinational Corporation be Regulated with Respect to Human Rights yang dikutip oleh Iman prihandono dalam Status dan Tanggung Jawab Multi-National Companies (MNCs) dalam Hukum Internasional, mengemukakan alasan mengapa perusahaan multinasional harus diberikan tanggung jawab dalam hukum internasional bahwa:

Setidaknya terdapat dua alasan mengapa perusahaan multinasional harus mempunyai tanggung jawab langsung menurut hukum internasional. Yaitu: Pertama, perusahaan multinasional mempunyai pengaruh yang sangat kuat terhadap kegiatan ekonomi sebuah negara (terutama di negara berkembang)

\footnotetext{
24 An an Chandrawulan. Op. Cit., hal. 184

25 Jimly Asshiddiqie. Hukum Tata Negara dan Pilar-Pilar Demokrasi. Cet.1. Sinar Grafika. Jakarta. 2011. hal. 136.

26 Iman Prihandono. Op. Cit., hal. 70.
} 
bahkan kadang mampu memiliki kekuatan monopoli pasar dan kewenangan mengatur persyaratan kerja bagi buruh-buruhnya. Kedua, di banyak negara berkembang, perusahaan multinasional mengelola kegiatan usaha yang berhubungan dengan pelayanan publik seperti transportasi, tenaga listrik dan telekomunikasi. Hal ini secara tidak langsung seperti memberikan sebagian dari kewenangan negara kepada perusahaan multinasional. ${ }^{27}$

\section{B. Personalitas Perusahaan Multinasional sebagai Subjek Hukum Internasional}

Hak untuk menentukan nasib sendiri merupakan hak yang istimewa karena muncul di dua kovenan. Berakar dari dekoloniasi sudah dijelaskan bahwa pada awalnya penentuan nasib sendiri dilihat sebagai mekanisme untuk negara agar dapat mendapatkan kemerdekaannya dari kekuatan-kekuatan kolonial. Deklarasi Sidang Umum PBB tentang Pemberian Kemerdekaan kepada rakyat-rakyat terjajah ${ }^{28}$ adalah sumbangsih klasik kepada lingkup penentuan nasib sendiri selama 50 tahun pertama lebih keberadaan PBB.

Setiap entitas dapat dikatakan mempunyai personalitas dalam hukum internasional karena memiliki status dan kapasitas yang diakui sebagai subjek pengemban hak dan kewajiban dalam hukum internasional. "Status entitas akan menentukan kekuatan dan kewajiban tertentu sedangkan kapasitas akan menghubungkan status dengan hak dan kewajiban tertentu,"29 sehingga personalitas merupakan penentu suatu entitas dikatakan sebagai subjek hukum internasional atau tidak.

Terdapat dua pendekatan mengenai entitas yang diakui sebagai subjek hukum internasional, pertama, pendekatan secara teoritis bahwa "ada dua teori tentang subyek hukum internasional yang berbeda sama lain. Yang

\footnotetext{
27 Ibid, hal. 71.

28 Resolusi Sidang Umum 1514 (XV), 1960.

29 Shaw N Malcolm. Op. Cit., hal. 193.
}

Uti Possidetis: Journal of International Law, Vol. 1, No. 1 (2020) 
satu menyatakan bahwa yang merupakan subyek hukum internasional adalah hanyalah negara, teori yang lain menyatakan bahwa yang merupakan subjek hukum internasional hanyalah individu". ${ }^{30} \mathrm{Kedua}$, pendekatan secara praktis bahwa personalitas melihat bahwa personalitas bukanlah suatu yang absolut, karena hukum internasional terus berkembang mengikuti keadaan masyarakat.

Pendekatan secara teori yang menyatakan bahwa hanya negara yang merupakan subjek hukum internasional merupakan konsep hukum teknis untuk menunjuk sekumpulan ketentuan hukum yang ada di suatu wilayah tertentu. ${ }^{31}$ Menurut teori ini pula, "individu bukanlah penanggung hak atau kewajiban yang lahir secara langsung dari hukum internasional. Apabila aturan-aturan hukum internasional melahirkan suatu hak yang memberi perlindungan kepada individu, maka ia hanya dapat memiliki atau mempertahankan haknya apabila ada dukungan dari negaranya". ${ }^{32}$ Berlawanan dengan teori tersebut terdapat pula teori yang menyatakan kebalikannya secara ekstrim bahwa sebenarnya individu merupakan subjek hukum internasional yang sesungguhnya. Teori ini dikemukakan oleh Hans Kelsen dalam bukunya Principles of International Law bahwa kewajiban negara sebenarnya adalah kewajiban semua manusia yang merupakan anggota masyarakat di suatu negara. ${ }^{33}$

Secara praktis membuktikan subjek hukum internasional bukan hanya negara atau individu namun dalam perkembangannya terdapat entitas lain yang diakui sebagai subjek hukum internasional seperti Organisasi Internasional, Palang Merah Internasional, Tahta Suci, Perusahaan Multinasional dan Pemberontak (Belligerent). Terdapat berbagai faktor yang mempengaruhi entitas tersebut sehingga diakui sebagai subjek hukum internasional, seperti faktor

\footnotetext{
30 Sugeng Istanto, Op. Cit., hal. 126.

31 Ibid., hal. 16.

32 Huala Adolf. Hukum Ekonomi Internasional Suatu Pengantar. Op.Cit., hal. 68.

33 Mochtar Kusumaatmadja dan Etty R. Agoes. Op. Cit., hal. 96-97.
} 
sejarah, kebutuhan perkembangan masyarakat hukum internasional dan karena kehendak dari hukum itu sendiri.

Perusahaan multinasional merupakan objek kajian dalam penulisan ini adalah suatu entitas yang patut dipertimbangkan untuk diakui personalitasnya sebagai subjek hukum internasional karena secara praktik melalui penanaman modal asing langsung (foreign direct investment) dapat mempengaruhi ekonomi dan kebijakan politik negara asal (home state) dan negara tuan rumah (host state). Setidaknya terdapat 3 (tiga) kemungkinan jawaban atas pertanyaan mengenai personalitas perusahaan multinasional dalam hukum internasional. Pertama, personalitas perusahaan multinasional dalam hukum internasional adalah sebagai subjek hukum internasional; Kedua, perusahaan multinasional tidak memiliki personalitas dalam hukum internasional sehinga bukanlah subjek hukum internasional; Ketiga, personalitas perusahaan multinasional dalam hukum internasional adalah sebagai quasi subjek hukum internasional (semu subjek hukum internasional).

Untuk menentukan jawaban atas pertanyaan mengenai personalitas perusahaan multinasional sebagai subjek hukum internasional atau hanya sebagai quasi subjek hukum internasional atau bahkan tidak memiliki personalitas sama sekali bukanlah perkara mudah. Para ahli hukum internasional masih memperdebatkannya. Selain itu, "pengertian perusahaan multinasional sendiri sebenarnya merupakan suatu pengertian yang dikenal dalam ilmu ekonomi. Ilmu hukum tidak mengenal sama sekali pengertian tersebut. karena itu pula dalam membahas masalah ini dari sudut hukum, upaya terhadapnya menjadi kontroversial dan bahkan sulit" 34 .

Pernyataan yang kontroversial dikemukakan oleh Francois Rigaux bahwa "it must be emphasized that transnational corporations are neither subjects nor quasisubjects of international law. ${ }^{\prime 35}$ (Terjemahan bebas: Sesuatu hal

\footnotetext{
34 Huala Adolf. Hukum Ekonomi Internasional Suatu Pengantar. Op.Cit., hal. 79.

35 Ibid., hal. 81 .
}

Uti Possidetis: Journal of International Law, Vol. 1, No. 1 (2020) 
yang harus ditekankan bahwa perusahaan multinasional bukanlah subjek dan quasi-subjek hukum internasional). Meskipun demikian, terjadinya perdebatan mengenai personalitas perusahaan multinasional dalam hukum internasional tidaklah mengabaikan realitannya yang diterima masyarakat internasional karena modal yang ditanam di wilayah negara lain tunduk kepada aturan hukum internasional. Perusahaan multinasional masih diperdebatkan juga personalitasnya dalam hukum internasional karena beberapa negara tidak bersedia untuk memaksa sebuah perusahaan multinasional bertanggung jawab atas kerugian yang ditimbulkan dari kegiatan usahanya di negara lain. ${ }^{36}$ Secara struktural, induk perusahaan yang berada di negara asal perusahaan multinasional bertindak sebagai pembuat keputusan terpusat mampu mengendalikan anak perusahaan yang berada di negara tuan rumah. Hal ini menunjukkan bahwa meskipun perusahaan tersebut didirikan berdasarkan hukum nasional negara tuan rumah tetapi tidak dapat bertindak bebas sesuai inisiatifnya.

Bila sudut pandang kita adalah liberalisasi perdagangan dalam kerangka aturan Organisasi Perdagangan Dunia (World Trade Organization) menjadi alasan pembenar aktivitas perusahaan multinasional dan modal yang ditanamnya di negara lain diatur dengan hukum internasional. Sejalan dengan itu, S.M Noormengemukakan bahwa:

"Perdebatan status MNCs, seharusnya tidaklah lantas membutakan realita yang ada bahwa eksistensi mereka harus dapat diterima dalam masyarakat hukum internasional. MNCs memainkan peran penting dalam kehidupan global sekarang ini dimana MNCs dapat melakukan kerjasama dan membuat persetujuan dengan pemerintah suatu negara dengan memberlakukan prinsip-prinsip umum hukum internasional atau aturan-aturan lainnya, yang pastinya mereka tidak diatur dengan ketentuan hukum nasional suatu negara atau dalam istilah kontrak biasa

36 Iman Prihandono. Op. Cit., hal. 72.

Uti Possidetis: Journal of International Law, Vol. 1, No. 1 (2020) 
disebut internationalized contracts, oleh karena itu, mengingat argumen yang dibangun diatas maka MNCs dapat dikatakan sebagai subjek hukum internasional". 37

Karakteristik perusahaan multinasional yang melintasi batas-batas negara dengan kekuatan ekonomi perusahaan multinasional menunjukkan peran induk perusahaan sebagai pembuat keputusan sentral dalam pengendalian anak-anak perusahaannya di negara tuan rumah sesuai dengan teori Associated-Dependent Development yang dikemukakan Fernando Hendrique Cardoso. Dalam teori ini, "pemilikan" industri nampaknya tidak penting, apakah dimiliki pihak asing, berbentuk perusahaan patungan atau perusahaan domestik yang bergabung dengan perusahaan-perusahaan asing, tetapi penekanan justru pada siapa yang mengambil keputusan. ${ }^{38}$ Dalam perusahaan multinasional sudah jelas yang mengambil keputusan adalah induk perusahaan, yang menjadi benang merah dari permasalahan ini adalah keputusan yang dibuat induk perusahaan seringkali bertentangan dengan kepentingan atau bahkan hukum negara tuan rumah (conflicting requirement on enterprises).

Jika pada akhirnya perusahaan multinasional memiliki personalitas dan diakui sebagai subjek hukum internasional maka perusahaan multinasional bisa mendapatkan posisi yang setara dengan negara dalam hukum internasional sehingga dapat mengajukan klaim melawan negara berdasarkan hukum internasional. Dalam hal ini negara tidak perlu khawatir jika perusahaan multinasional mendapatkan kedudukan seperti negara karena negara juga berhak mengajukan klaim hukum melawan perusahaan multinasional apabila dinilai telah melakukan pelanggaran sehingga pembebanan tanggung jawab dalam hukum internasional dapat dipaksakan

37 www.negarahukum.com, Perusahaan Multinasional (Multinational Corporations-MNCs), www.negarahukum.com/hukum/perusahaanmultinational-multinational., terakhir diakses 3 Maret 2016, Pukul 14:37 WIB.

38 IJ. Heryanto. Peranan Multinational Corporations Dalam Industrialisasi Di Indonesia Pada Era Orde Baru. Jurnal Manajemen \& Kewirausahaan. Vol. 5. No. 1. Maret 2003. hal. 20. 
kepadanya. Selain itu, jika hukum internasional mengakui personalitas perusahaan multinasional sebagai subjek dalam hukum internasional maka perusahaan multinasional dapat menjadi pihak dalam perjanjian internasional dan merumuskannya.

Perspektif hukum membuktikan perdebatan mengenai personalitas perusahaan multinasional dalam hukum internasional tentu berujung kepada telah dipenuhi atau tidak unsur kecakapan sebagai persyaratan untuk menjadi subjek hukum internasional karena jika terus memperdebatkan tetapi tidak jelas kecakapannya maka keberadaan perusahaan multinasional akan terus menimbulkan pertanyaan. Menurut Ian Brownlieterdapat tiga syarat, apabila hanya satu saja dipenuhi maka suatu entitas diakui sebagai subjek hukum internasional: "Pertama, adanya kapasitas untuk melakukan gugatan dalam hal terjadi pelanggaran hukum internasional. Kedua, adanya kapasitas untuk menandatangani perjanjian internasional. Ketiga, adanya privilege dan imunitas yang lahir dari natural jurisdiction." 39 .

Persyaratan pertama menunjukkan bahwa untuk melakukan gugatan dalam hukum internasional harus memiliki kewenangan hukum (standing). Dalam hal ini perusahaan multinasional tidak memiliki kewenangan hukum (standing) untuk berperkara di Mahkamah Internasional (International Court of Justice) karena telah diatur secara jelas dalam Pasal 34 ayat (1) Statuta Mahkamah Internasional, yang menyatakan bahwa hanya negara yang dapat menjadi pihak dalam perkara didepan Mahkamah.

Meskipun demikian, pengalaman menunjukkan bahwa Indonesia mengakui bahwa perusahaan multinasional memiliki kewenangan hukum untuk menyerahkan sengketa ke badan Internasional pada kasus Hotel Kartika antara Indonesia dengan PT AMCO, sebuah perusahaan asing yang diselesaikan oleh badan arbitrase ICSID (International for the Settlement of Investment Disputes) di Washington. ${ }^{40}$ Dalam

\footnotetext{
39 Iman Prihandono. Loc., Cit.

40 Huala Adolf. Hukum Ekonomi Internasional Suatu Pengantar. Op.Cit., hal. 88.
} 
kasus ini Indonesia kalah dan harus membayar kompensasi sebesar 3.2 Juta Dollar AS atas akuisisi pengelolaan Hotel Kartika Plaza. ${ }^{41}$ Berdasarkan ketentuan Pasal 32 ayat (4) Undang-Undang Nomor 25 Tahun 2007 Tentang Penanaman Modal diatas, terlihat bahwa Indonesia telah mengakui dan mengatur mekanisme penyelesaian sengketa penanaman modal dengan perusahaan multinasional tidak cukup diselesaikan dengan badan arbitrase nasional namun terdapat badan arbitrase internasional yang lebih berkompeten menyelesaikannya. Hal ini membuktikan bahwa Indonesia mengakui perusahaan multinasional memiliki personalitas dan sebagai subjek hukum internasional yang terbatas.

Persyaratan kedua menunjukkan bahwa untuk menjadi subjek hukum internasional maka perusahaan multinasional harus terlibat aktif dalam perjanjian internasional. Dalam hal ini perusahaan multinasional tidak mempunyai kecakapan untuk menandatangani perjanjian internasional karena tidak ada instrumen dalam hukum internasional yang memberikan wewenang kepada perusahaan multinasional sebagai pihak dalam perjanjian internasional. Konvensi Wina Tahun 1969 tentang Perjanjian Internasional hanya menyebutkan bahwa hanya negara yang berhak menjadi pihak dalam perjanjian internasional, ${ }^{42}$ Konvensi Wina 1986 tentang Perjanjian Internasional juga tidak memberikan wewenang kepada perusahaan multinasional karena yang berhak menandatangani perjanjian internasional adalah antara negara dengan negara, negara dengan organisasi internasional dan antara suatu organisasi internasional dengan organisasi internasional lainnya. ${ }^{43}$ Selain ketentuan tersebut, terdapat pula entitas yang telah diakui sebagai subjek hukum internasional dianggap cakap menandatangani perjanjian internasional seperti perjanjian

${ }^{41}$ Ir.binus.ac.id, Melawan Bullying Perusahaan Multinasional, Ir.binus.ac.id/2014/05/15/melawan-bullying-perusahaanmultinasional, terakhir diakses 3 Maret 2016 Pukul 15.03 WIB.

42 Lihat Pasal 2 Konvensi Wina Tahun 1969 Tentang Perjanjian Internasional.

43 Lihat Pasal 2 Konvensi Wina Tahun 1986 Tentang Perjanjian Internasional. 
antara Tahta Suci dengan negara-negara berkaitan dengan halhal keagamaan, karena Tahta Suci merupakan subjek hukum yang diakui dalam hukum internasional. ${ }^{44}$

Tidak terdapatnya instrumen hukum yang mengatur perusahaaan multinasional sebagai pihak dalam penandatanganan perjanjian internasional menjadikan perusahaan multinasional tidak dapat dikatakan sebagai subjek hukum internasional.Meskipun demikian, "dalam halhal tertentu perusahaan multinasional dapat membuat persetujuan dengan pemerintah suatu negara dengan memberlakukan prinsip hukum internasional atau prinsip hukum umum untuk transaksi mereka dan bukan diatur oleh hukum nasional suatu negara". ${ }^{45}$ Prinsip-prinsip perdagangan internasional yang terdapat dalam ketentuan Organisasi Perdagangan Dunia (World Trade Organization) berkaitan dengan penanaman modal oleh perusahaan multinasional yaitu prinsip perlakuan nasional (National Treatment) yang menunjukkan negara harus memberikan perlakuan yang sama dengan tidak membeda-bedakan antara penanam modal yang berasal dari dalam maupun berasal dari luar negeri dan prinsip perlakuan yang sama kepada semua negara (Most Favoured Nation) dengan tidak membedakan mitra dagang antara negara satu dengan negara lainnya. ${ }^{46}$

Wewenang hukum perusahaan multinasional membuat persetujuan dengan suatu negara misalnya terdapat dalam konvensi ICSID (Convention on the settlement of Investment Disputes Between States and Nationals of Other States) tahun 1965. Konvensi ICSID secara implisit memberikan wewenang kepada perusahaan multinasional untuk membuat kontrak atau penanaman modal dengan suatu negara. Kemampuan perusahaan multinasional membuat kontrak tersebut dilakukan oleh individu dalam artian badan

44 Mochtar Kusumaatmadja dan Etty R. Agoes. Op. Cit., hal. 118.

45 Boer Mauna. Op. Cit., hal. 56.

46 Ketentuan mengenai prinsip National Treatmentdapat dilihat dalamPasal III General Agreement on Tariffs and Trade dan Pasal II Trade Related Investment Measures, sedangkan Ketentuan mengenai prinsip Most Favoured Nations terdapat dalam Pasal 1 General Agreement on Tariffs and Trade.

Uti Possidetis: Journal of International Law, Vol. 1, No. 1 (2020) 
hukum (juridical person). Sebagai catatan, Menurut Huala Adolfperusahaan multinasional perlu diadakan pemisahan dengan individu atau sekedar badan hukum. Perusahaan multinasional memiliki personalitas lebih tinggi dibanding individu, karena itu perlakuan terhadapnya perlu dibedakan dalam pengkajian sebagai subjek hukum internasional. ${ }^{47}$

Kemampuan perusahaan multinasional membuat kontrak dengan negara tuan rumah menggunakan prinsip umum hukum internasional yang terdapat dalam kerangka aturan liberalisasi perdagangan mensyaratkan adanya pembatasan kewenangan negara terhadap hak-hak ekonominya melalui pemberian hak-hak kepada perusahaan multinasional atau dengan kata lain perusahaan multinasional diberikan kewenangan mereduksi kekuasaan perekonomian negara tuan rumah. Persyaratan kedua ini juga membuktikan bahwa dalam hukum Internasional telah adanya upaya untuk memberikan kecakapan yang semu kepada perusahaan multinasional.

Persyaratan ketiga tentu perusahaan multinasional tidak memenuhinya karena secara umum hanya negara yang memiliki wilayah dan kedaulatan atas wilayah tersebut ${ }^{48}$. Semua negara, berdasarkan prinsip kesetaraan kedaulatan, akan mendapatkan kadar personalitas hukum yang sama. ${ }^{49}$

Dari penjelasan diatas terlihat bahwa perusahaan multinasional tidak memenuhi kriteria kecakapan sebagai subjek internasional, namun dalam hal ini hukum internasional telah mengakui personalitas perusahaan multinasional meskipun dalam kadar yang terbatas sehingga dapat dikatakan bahwa perusahaan multinasional diakui sebagai quasi subjek hukum internasional.

Personalitas perusahaan multinasional sebagai quasi subjek hukum internasional di dukung Menno $\mathrm{T}$ Kamminga dan Saman Zia Arifi dalam Liability of Multinational Corporations Under International Law sebagaimana dikutip An An

47 Huala Adolf. Hukum Ekonomi Internasional Suatu Pengantar. Op.Cit., hal. 78.

Shaw N Malcolm. Op. Cit., hal. 236. 
Chandrawulan dalam Hukum Perusahaan Multinasional yang menyatakan bahwa:

“...Statusnya sebagai quasi subjek hukum internasional tampak dari muatan instrumen seperti Organisasi Perdagangan Dunia (WT0), Bank Dunia dan IMF yang menunjukkan berkembangnya tuntutan terhadap perlu adanya keseimbangan antara hak-hak dan kewajibankewajiban dari perusahaan multinasional sebagai quasi subjek hukum internasional yang mempunyai kepentingan sebagai pelaku (aktor) yang memiliki kekuasaan sebagai quasi kekuasaan negara". 50

Berkembangnya tuntutan terhadap terhadap perlunya ada keseimbangan antara hak dan kewajiban perusahaan multinasional memperlihatkan bahwa semakin berkurangnya peran otoritas pemerintah terhadap kebijakan perekonomian di negaranya. Peran tersebut mengisyaratkan telah tersistem dalam hukum internasional dan perusahaan multinasional ikut andil mengikuti pola-pola tersebut. John Ruggiemenyatakan bahwa:

Pola korporasi yang menerapkan pelaksanaan sistem ekonomi liberalisme baru ini telah terkonstruksi di dalam kehidupan masyarakat yang kemudian menjadi sebuah patokan identitas dan ciri khas yang mengisyaratkan keberadaan aspek ekonomi nasional di sebuah negara. Didalam penerapannya mengenai prinsip-prinsip neoliberalisme ini, korporasi cenderung mengurangi peranan pemerintah didalam praktek ekonominya sehingga arena politik internasional pada masa globalisasi ini memiliki perbedaan yang radikal

50 An An Chandrawulan. Hukum Perusahaan Multinasional. Op. Cit., hal. 180 .

Uti Possidetis: Journal of International Law, Vol. 1, No. 1 (2020) 
yang dicirikan dengan absennya peran pemerintah di sebuah negara. 51

Berkurangnya peran pemerintah di sebuah negara terhadap kekuasaan perekonomian pernah dialami oleh Indonesia, "sewaktu pemerintah RI mengeluarkan Inpres Nomor 2 Tahun 1996 mengenai kebijakan otomotif nasional, serta merta negara-negara industri otomotif terkemuka, Amerika Serikat, Jepang dan Uni Eropa, memprotes kebijakan dalam Inpres itu".52 Inpres tersebut telah melanggar prinsipprinsip hukum perdagangan internasional karena memberi perlakuan khusus kepada suatu produsen otomotif nasional. Hal ini menunjukkan bahwa apa yang sebelumnya menjadi kewenangan penuh suatu negara berdaulat menjadi berkurang manakala terdapat kepentingan ekonomi negara lain terganggu olehnya.

Dari berbagai penjelasan diatas dapat dikatakan bahwa personalitas perusahaan multinasional dalam hukum internasional terbatas sebagai quasi subjek hukum internasional karena tidak dipenuhinya persyaratan sebagai subjek hukum internasional dengan tidak dapat menjadi pihak dalam penandatanganan perjanjian internasional namun perusahaan mempunyai kapasitas membuat kontrak penanaman modal dengan negara tuan rumah yang pengaturannya menggunakan prinsip-prinsip hukum perdagangan internasional khususnya prinsip National Treatment dan Most Favoured Nations. Selain itu, perusahaan multinasional juga tidak memenuhi persyaratan sebagai subjek hukum internasional dalam hal menjadi pihak yang dituntut dalam gugatan internasional akan tetapi perusahaan

51 www.unair.ac.id, Postur Korporasi dan Responsibilitas didalam Era Globalisasi. http://louis-embun-fisip13.web.unair.ac.id/artikel_, terakhir diakses tanggal 3 Maret 2016, Pukul 16.19 WIB.

52 Huala Adolf. Hukum Ekonomi Internasional Suatu Pengantar. Op.Cit., hal. 2. 
multinasional dapat menjadi pihak dalam penyelesaian sengketa internasional terbatas kasus sengketa penanaman modal dengan negara tuan rumah yang diselesaikan melalui arbitrase internasional.

Seperti yang telah dikemukakan sebelumnya bahwa hukum internasional telah mengakui personalitas perusahaan multinasional dalam kadar yang terbatas, sehingga instrumen hukum internasional tidak dapat diterapkan sepenuhnya kepada perusahaan multinasional. Sebagai quasi subjek hukum internasional peran perusahaan multinasional dapat dikatakan mengambil hak-hak negara terhadap perekonomian atau dalam artian telah mereduksi kekuasaan negara sehingga muncul kembali persoalan dapat atau tidaknya perusahaan multinasional dibebankan tanggung jawab dalam hukum internasional.

Perusahaan multinasional dimungkinkan untuk bertanggung jawab berdasarkan hukum internasional, seperti halnya individu yang memperoleh personalitas akibat secara langsung terkena beban kewajiban internasional dalam kasus tertentu seperti kejahatan perang, pembajakan dan kejahatan genosida. Oleh karena itu, dengan menggunakan metode yang sama masih terdapat kemungkinan perusahaan multinasional dibebankan tanggung jawab berdasarkan hukum internasional.

Teori klasik dalam hukum internasional tidak pernah menyatakan bahwa hanya tindakan pelanggaran oleh negara saja yang dapat dikatagorikan sebagai bentuk pelanggaran hukum internasional (internationally wrongful act). Setidaknya sebuah sumber hukum internasional yang berlaku sebagai sumber hukum sekunder atau secondary international law telah mengakui bahwa tindakan individu (person) atau sekelompok orang (group of persons) dapat dikenai tanggung jawab internasional bila individu atau 
sekelompok individu tersebut secara nyata menjalankan tugas atau kewenangan penguasa negara. Demikian juga tindakan non-state actors dapat dibebani tanggung jawab hukum internasional bila negara mengakui dan mengambil alih tindakan tersebut sebagai tindakan negara yang bersangkutan. ${ }^{53}$

Perkembangan hukum internasional belum menunjukkan perusahaan multinasional dapat dibebankan tanggung jawab berdasarkan hukum internasional, meskipun hadirnya perusahaan multinasional yang mereduksi kekuasaan negara namun hukum internasional masih menempatkan negara sebagai pemilik kekuasaan tertinggi dan bertanggung jawab atas setiap subjek dan obyek yang berada diwilayahnya.

Negara sebagai pemegang kekuasaan tertinggi atau dikenal dengan kedaulatan negara (state sovereignty) mengatur aktivitas perusahaan multinasional yang berada di wilayahnya, apabila perusahaan multinasional melalaikan kewajibannya seperti pelanggaran hak asasi manusia, perusakan lingkungan dan pelanggaran hak-hak buruh dapat dibebankan tanggung jawab berdasarkan hukum nasional. Sedangkan hukum internasional berupaya mengaturnya dengan berbagai perjanjian internasional yang berupaya mengindikasikan tanggung jawab tersebut juga hanya dapat dipaksakan melalui kewenangan negara.

Mochtar Kusumaatmadjaberpendapat bahwa perjanjian internasional mengakibatkan timbulnya hak dan kewajiban bagi para pesertanya. ${ }^{54}$ Perjanjian internasional yang berkaitan dengan perusahaan multinasional misalnya instrumen perjanjian di bawah rejim Organisasi Perdagangan Dunia (WTO), Masyarakat Eropa (European Community), NAFTA (The North American Free Trade Agreement), OECD

53 Iman Prihandono., Op., Cit., hal. 73.

54 Mochtar Kusumaatmadja dan Etty R. Agoes. Op. Cit., hal. 123-124.

Uti Possidetis: Journal of International Law, Vol. 1, No. 1 (2020) 
(the Organization for Economic Cooperation and Development), dan berbagai Perjanjian Penanaman Modal Bilateral (Bilateral Investment Treaties) antara negara-negara pemilik modal terhadap perusahaan multinasional. 55

Perjanjian internasional yang mengatur perusahaan multinasional tersebut memperlihatkan melajunya liberalisasi tidak benar-benar mengekang aktivitas perusahaan multinasional atau dengan kata lain tidak adanya ketentuan dalam perjanjian internasional yang memuat perusahaan multinasional bertanggung jawab secara langsung atas pelanggaran dan kejahatan dalam hukum internasional, akan tetapi sebaliknya dengan adanya berbagai perjanjian internasional tersebut mereduksi kekuasaan negara dan melindungi aktivitas perusahaan multinasional.

Selain bersumber dari perjanjian internasional terdapat pula ketentuan dalam hukum internasional yang bersifat soft law yang berupaya mengatur aktivitas perusahaan multinasional, namun karena sifatnya tersebut maka ketentuannya tidak dapat dipaksakan. Ketentuan yang bersifat soft law misalnya terdapat dalam OECD Guidelines For Multinational Enterprises yakni pedoman yang di buat oleh Organisasi Untuk Kerjasama Ekonomi Dan Pembangunan (Organization For Economic Cooperation) bagi perusahaan multinasional. Pedoman ini merupakan rekomendasirekomendasi yang memuat prinsip-prinsip dan standarstandar perilaku bisnis yang bertanggung jawab bagi perusahaan multinasional secara keseluruhan baik anak perusahaan yang beroperasi di negara tuan rumah maupun induk perusahaan yang berada di negara asal.

OECD Guidelines For Multinational Enterprises berisikan rekomendasi kepada perusahaan multinasional untuk membuka tidak hanya informasi laporan keuangan, akan

55 An An Chandrawulan. Op. Cit., hal. 181.

Uti Possidetis: Journal of International Law, Vol. 1, No. 1 (2020) 
tetapi juga laporan lainnya yang meliputi informasi mengenai pengelolaan lingkungan hidup dan sosial. Panduan ini memberikan rekomendasi khusus kepada perusahaan multinasional berkaitan dengan pemberantasan korupsi, penghapusan kerja paksa dan tidak mempekerjakan anak dibawah umur, perlindungan konsumen, penggunaan teknologi dan ilmu pengetahuan, persaingan usaha yang sehat, kepatuhan terhadap aturan perpajakan dan pengelolaan lingkungan hidup.Walaupun "pedoman ini secara hukum tidak mengikat, tetapi perusahaan mempunyai kewajiban moral dan politik untuk menghormati dan melaksanakannya". ${ }^{56}$

Contoh lain ketentuan dalam hukum internasional bersifat soft law dibentuk oleh Organisasi Perburuhan Internasional (International Labour Organization) yang menyepakati terbentuknya ILO Tripartite Declaration of Principles Concerning Multinational Enterprises and Social Policy yang merupakan panduan internasional mengenai perusahaan dan interaksi mereka dengan isu tenaga kerja dan kebijakan sosial. Deklarasi ini memuat panduan bagi perusahaan multinasional, pemerintah, asosiasi pengusaha dan serikat pekerja di bidang-bidang ketenagakerjaan, pelatihan, kondisi kerja dan hidup, dan hubungan industrial. Tujuan deklarasi ini adalah mendorong perusahaan untuk memberikan kontribusi positif terhadap kemajuan ekonomi maupun sosial. Oleh karena sifatnya tersebut maka tidak ada kewajiban yang dapat dipaksakan kepada perusahaan multinasional.

Selain itu, ketentuan yang juga bersifat soft law terdapat pada The United Nations Global Compact yang merupakan inisiatif kebijakan strategis bagi perusahaanperusahaan yang berkomitmen untuk menyelaraskan

56 Ketentuan bersifat Soft Law dapat dilihat pada Foreword (Pendahuluan) dalam OECD Guidelines For Multinational Enterprises

Uti Possidetis: Journal of International Law, Vol. 1, No. 1 (2020) 
kebijakan dan operasi strategis usahanya dengan 10 (sepuluh) prinsip universal dibidang hak asasi manusia, perburuhan, lingkungan dan anti korupsi. Perkembangan terkini, lebih dari 10.000 perusahaan dan pemangku kepentingan yang berasal lebih dari 145 negara telah berpartisipasi sesuai inisiatifnya sendiri dan secara sukarela mengadopsi prinsip-prinsip yang terkandung dalam The United Nations Global Compact. ${ }^{57}$ Penjabaran prinsip-prinsip yang dimaksud yakni sebagai berikut:

1) Businesses should support and respect the protection of internationally proclaimed human rights (bisnis harus mendukung dan menghormati perlindungan hak asasi manusia internasional);

2) Make sure that they are not complicit in human rights abuses (memastikan bahwa perusahaan atau korporasi tidak terlibat dalam pelanggaran hak asasi manusia);

3) Businesses should uphoud the freedom of association and the effective recognition of the right to collective bargaining (bisnis harus menjunjung tinggi kebebasan berserikat dan pengakuan hak untuk berunding bersama secara efektif);

4) The elimination of all forms of forced and compulsory labour (penghapusan segala bentuk kerja paksa dan kerja wajib);

5) The effective abolition of child labour (penghapusan pekerja anak secara efektif);

6) The elimination of discrimination in respect of employment and occupation (penghapusan diskriminisi dalam hal pekerjaan dan jabatan);

7) Businesses should support a precautionary approach to environmental challenges (bisnis harus mendukung pendekatan pencegahan terhadap tantangan lingkungan);

57 Kristian. Hukum Korporasi Ditinjau Dalam The Unite Nations Global Compact (Suatu Pengantar). Nuansa Aulia. Bandung. 2014. hal. 1-2. 
8) Undertake initiatives to pomote greater environmentally responsibility (melakukan inisiatif untuk mempromosikan tanggung jawab lingkungan yang lebih besar);

9) Encourage the development and diffusion of environmentally friendly technologies (mendorong pengembangan dan penyebaran teknologi ramah lingkungan);

10) Businesses should work against corruption in all its forms, including extortion and bribery (bisnis harus bekerja melawan korupsi dalam segala bentuknya, termasuk pemerasan dan penyuapan). ${ }^{58}$

Pada dasarnya 10 (sepuluh) prinsip Global Compact Perserikatan Bangsa-Bangsa (The Ten Principles The United Nations Global Compact) tidak mengikat secara hukum karena merupakan inisiatif dan sukarela dari peserta. Dengan demikian tidak ada polisi atau badan-badan khusus untuk menegakkan perilaku atau tindakan perusahaan, sebaliknya Global Compact dirancang untuk merangsang perubahan dan untuk mempromosikan good corporate citizenship, mendorong solusi inovatif dan mengembangkan kemitraaan perusahaan dengan masyarakat sipil, pemerintah dan para pemangku kepentingan lainnya. ${ }^{59}$

Terkhusus dibidang hak asasi manusia, Kelompok Kerja PBB tentang Bisnis dan HAM (UN Working Group on Business and Human Rights) telah mengajukan secara resmi PrinsipPrinsip Pedoman International Mengenai Bisnis dan HAM (International Guiding Principles for Business and Human Rights) kepada Dewan HAM PBB (UN Human Rights Council) pada tahun 2010 yang lalu. Kemudian diadopsi oleh Majelis Umum PBB (UN General Assembly) pada 7 Juli 2011 dalam sidang Majelis Umum PBB sebagai acuan resmi bagi para pelaku usaha dalam menerapkan prinsip-prinsip HAM di

58

Ibid., hal. 31.

Ibid., hal. 194.

Uti Possidetis: Journal of International Law, Vol. 1, No. 1 (2020) 
dalam praktik bisnis. Prinsip-prinsip tersebut disusun oleh John Ruggieyang kemudian tercantum dalam Guiding Principles for Business and Human Rights. ${ }^{60}$

Terdapat tiga prinsip yang tercantum dalam Guiding Principles for Business and Human Rights. Prinsip pertama tentang The State to Duty to Protect berkaitan dengan kewajiban negara melindungi warga negaranya terhadap pelanggaran HAM dari pihak ketiga termasuk perusahaan multinasional melalui kebijakan, peraturan dan peradilan yang adi, karena adalah mustahil mewujudkan cita-cita rule of law sementara posisi dan peran negara sangat minimal, atas dasar itulah kemudian, negara diberi kebebsan bertindak.61 Prinsip kedua tentang Corporate Responsibility to Respect for Human Rights berkaitan dengan tanggung jawab badan usaha untuk menghormati HAM yang berarti bahwa perusahaan harus bertindak dengan uji tuntas untuk menghindari dan mengatasi dampak atas pelanggaran HAM di negara tempat beroperasi. Prinsip terakhir tentang Access to Remedy, yakni badan usaha dan negara wajib memberikan akses yang lebih luas kepada para korban terkait dengan tindakan badan usaha baik diluar maupun didalam pengadilan.

Perusahaan multinasional dalam hal ini hanya bertanggung jawab menghormati HAM, sedang fungsi perlindungan HAM terletak pada negara karena pemilik warga negaranya. Dalam hal perhormatan HAM, perusahaan multinasional berkewajiban mengikuti ketentuan yang telah diatur oleh negara misalnya ketika negara menerapkan

60 www.lintasgayo.com, Tanggung Jawab Sosial dan Lingkungan Perusahaan, Bisnis dan Hak Asasi Manusia, www.lintasgayo.com/tanggung-jawab-sosial-dan-lingkunganperusahaan-bisnis-dan-hak-asasi-manusia.html, terakhir diakses tanggal 3 Maret 2016. Pukul 16.25 WIB.

61 Retno Kusniati. Sejarah Perlindungan Hak-Hak Asasi Manusia dalam Kaitannya dengan Konsepsi Negara Hukum. Jurnal Ilmu Hukum. 2011. diakses dari http://unja.ac.id 
standar upah minimum upah bagi pekerja maka perusahaan berkewajiban menerapkan standar yang ditetapkan negara tersebut. ${ }^{62}$ Hal lain yang dapat dilakukan oleh perusahaan multinasional adalah dengan memberikan akses informasi global kepada konsumen mengenai segala jenis aktivitas bisnisnya sehingga setiap aktivitas yang dijalankan memiliki tanggung jawab untuk senantiasa menghormati hak asasi manusia.

Prinsip internasional yang disusun John Ruggie tersebut menunjukkan bahwa perusahaan multinasional dapat menjadi subjek pengemban HAM internasional dalam arti yang terbatas pada penghormatan yang diatur dengan ketentuan internasional sedangkan untuk pembebanan tanggung jawab dalam hukum internasional tidak dapat diterapkan secara langsung karena negara punya hak atas kedaulatannya.

Dapat dikatakan bahwa belum terdapatnya ketentuan bersifat hard law dalam hukum yang membebankan perusahaan multinasional bertanggung jawab sebagai pihak yang dapat dituntut atas pelanggaran dan kejahatan dalam hukum internasional. Ketentuan yang bersifat soft law juga demikian, meskipun telah ada upaya untuk mengatur perusahaan multinasional dengan prinsip-prinsip dan standar pengaturan secara internasional agar aktivitas usahannya lebih bertanggung jawab namun karena sifatnya yang tidak mengikat dan tidak dapat dipaksakan secara hukum sehingga akan berlaku melalui perantara negara dengan mengaturnya dalam aturan nasional serta akan berlaku pula jika perusahaan multinasional mengadopsinya kedalam praktik.

Berdasarkan telaah diatas, pembebanan tanggung jawab kepada perusahaan multinasional dalam hukum internasional

62 Rehulina. Multinational Corporations Sebagai Pengemban Kewajiban dalam Hukum Hak Asasi Manusia Training Tingkat Lanjut Rule of Law dan Hak Asasi Manusia Bagi Dosen Hukum dan HAM. Jakarta. 3-6 Juni 2015. hal. 9. 
dapat dilakukan dengan mengakuinya sebagai pihak yang dapat dituntut atas pelanggaran dan kejahatan internasional seperti halnya individu yang bertanggung jawab dalam kasus tertentu karena diatur dengan ketentuan bersifat hard law yang berbentuk perjanjian internasional. Selain itu, ketentuan bersifat soft law dalam hukum internasional yang mengatur perusahaan multinasional dengan prinsip-prinsip dan standar pengaturan internasional perlu dijadikan hard law mengingat kepastian mengikatnya ketentuan tersebut sehingga aktivitas perusahaan multinasional lebih bertanggung jawab kepada aturan hukum negara tuan rumah. Sebagai catatan, meskipun ketentuan yang bersifat soft law telah menjadi hard law namun harus tetap ada rumusan ketentuan yang berintikan perusahaan multinasional harus bertanggung jawab atas kejahatan dan pelanggaran dalam hukum internasional karena tanggung jawab hanya melalui perantara aturan hukum negara tuan rumah tidaklah cukup membenani perusahaan multinasional dalam aktivitas bisnisnya.

Jika pada akhirnya perusahaan multinasional dibebankan tanggung jawab dalam hukum internasional berarti juga menunjukkan pengakuan secara jelas mengenai personalitas perusahaan multinasional sebagai subjek hukum internasional, namun dalam hal kewenangan harus diberikan hak yang terbatas. Terbatas maksudnya jika negara-negara tidak bersedia untuk setara dengan perusahaan multinasional dalam pembuatan perjanjian internasional maka tidak perlu diberikan kewenangan tersebut kepada perusahaan multinasional. Dalam hal ini, perusahaan multinasional cukup diberikan kewenangan melakukan membuat persetujuan dengan suatu negara menggunakan prinsip-prinsip hukum perdagangan internasional. 


\section{Simpulan}

Permasalahan hak menentukan nasib sendiri di Indonesia bisa dilihat dari dua perspektif, yaitu internal selfdetermination dan external self-determination, permasalahan ini biasanya terfokus pada konflik antar masyarakat dikarenakan isu rasial, ekonomi dan latar belakang agama. Permasalahan ini juga berlaku untuk banyak komunitas dan provinsi yang mencari hak otonomi dan hak istimewa yang lebih tinggi dari pemerintah pusat, pada akhirnya memicu keinginan masyarakat untuk membuat gerakan memisahkan diri dari Indonesia. Pengaturan hak menentukan nasib sendiri dalam hukum internasional sebagai salah satu Hak Asasi Manusia diatur dalam instrumen internasional yaitu Piagam PBB, Kovenan Internasional tentang Hak-hak Sipil dan Politik, Kovenan Internasional tentang Hak-hak Ekonomi, Sosial dan Budaya, Deklarasi tentang Pemberian Kemerdekaan kepada Negara-negara dan Bangsa-bangsa Jajahan, Deklarasi Wina dan Program Aksi 1993 serta Mahkamah Internasional dalam Advisory Opinion kasus Western Sahara yang menegaskan hak menentukan nasib sendiri hanya dapat diberikan kepada wilayah jajahan, wilayah perwalian dan non self-governing territories.

Papua Barat tidak termasuk di dalam 3 kategori dalam hak menentukan nasib sendiri yaitu negara jajahan (koloni) karena sejak awal merupakan bagian dari Indonesia, bukan merupakan wilayah perwalian dan Papua Barat tidak pernah masuk di dalam daftar wilayah tidak berpemerintahan sendiri (non self-governing territories), menyebabkan Papua Barat tidak dapat mengusung hak menentukan nasib sendiri, selanjutnya transfer otoritas dari United Nations Temporary Executive Authority (UNTEA) dan hasil dari Act of Free Choice mempertegas kedaulatan Indonesia di Papua Barat. Penerapan hak menentukan nasib sendiri berhadapan dengan Teritorial Integrity dan doktrin Uti Possidetis juris. 


\section{Referensi}

\section{Instrumen Hukum}

Agreement Establishing The World Trade Organization.

Convention on the settlement of Investment Disputes Between

States and Nationals of Other States.

Guiding Principles for Business and Human Rights.

ILO Tripartite Declaration of Principles Concerning Multinational Enterprises and Social Policy.

Republik Indonesia. Undang-Undang Tentang Penanaman Modal. UU Nomor 25 Tahun 2007. LNRI Tahun 2007 Nomor 67. TLNRI Nomor 4724.

------, Undang-Undang Tentang Perseroan Terbatas. UU Nomor 40 Tahun 2007. LNRI Tahun 2007 Nomor 106. TLNRI Nomor 4756.

------, Undang-Undang Tentang Pengesahan Agreement Establishing The World Organization. UU Nomor 7 Tahun 1994. LNRI Tahun 2007 Nomor 57. TLNRI Nomor 3556.

The OCDC Guidelines for Multinational Enterprises.

The United Nations Global Impact.

\section{Buku}

Adolf, Huala. Hukum Ekonomi Internasional Suatu Pengantar. Cet. 4. Raja Grafindo Persada, Jakarta, 2005.

------, Perjanjian Penanaman Modal dalam Hukum Perdagangan Internasional (WTO). Cet. 2. Keni Media, Bandung, 2010.

Asshiddiqie, Jimly. Hukum Tata Negara dan Pilar-Pilar Demokrasi. Cet. 1. Sinar Grafika, Jakarta, 2011.

------, Teori Hans Kelsen Tentang Hukum. Cet. 3. Konstitusi Press, Jakarta, 2012.

Buku Panduan Fakultas Hukum Universitas Jambi, 2015. Chandrawulan, An An. Hukum Perusahaan Multinasional, Liberalisasi Hukum Perdagangan Internasional dan Hukum Penanaman Modal. Alumni, Bandung, 2011. 
------, Hukum Perusahaan Multinasional. Keni Media, Bandung, 2014.

Fuady, Munir. Hukum Dagang Internasional (Aspek Hukum dari WTO). Cet. 1. Citra Aditya Bakti, Bandung, 2004.

HR, Ridwan. Hukum Administrasi Negara. Cet. 17. Raja Grafindo Persada, Jakarta, 2011.

Istanto, Sugeng. Hukum Internasional. Cet. 2. Penerbitan Universitas Atma Jaya Yogyakarta, Yogyakarta, 1998.

Kristian. Hukum Korporasi Ditinjau Dalam The Unite Nations Global Compact (Suatu Pengantar). Nuansa Aulia, Bandung, 2014.

Malcom, Shaw N. Hukum Internasional (International Law) diterjemahkan oleh Derta Sri Widowatie, Imam Baehaqi dan M. Khozim. Nusa Media, Bandung, 2013.

Maman Suherman, Ade. Hukum Perdagangan Internasional: Lembaga Penyelesaian Sengketa WTO dan Negara Berkembang. Cet. 1. Sinar Grafika, Jakarta Timur, 2000.

Marzuki, Peter Mahmud. Penelitian Hukum, Cet. 8. Edisi Revisi. Kencana Prenada Media Group, Jakarta, 2013.

Mauna, Boer. Hukum Internasional Pengertian, Peran dan Fungsi dalam Dinamika Global. Alumni, Bandung, 2011.

Putra, Ida Bagus Wiyasa. Aspek-Aspek Hukum Perdata Internasional dalam Transaksi Bisnis Internasional. Refika Aditama, Bandung, 2000.

Ramlan. Hukum Internasional. Fakultas Hukum Universitas Jambi, 2008.

Sulistiowati. Tanggung Jawab Hukum pada Perusahaan Grup di Indonesia. Erlangga, Jakarta, 2013.

\section{Artikel/Jurnal}

Ascarya, Sri Mulyati dan Tri Subari, "Kebijakan Sistem Pembayaran di Indonesia, Pusat Pendidikan Dan Studi Kebanksentralan (Ppsk) Bank Indonesia", Jakarta, 2001. 
Bank Indonesia, "Laporan Sistem Pembayaran dan Pengedaran Uang 2009; Peran dan Kinerja Sistem Pembayaran dalam Mendukung Upaya Pemulihan Ekonomi", Jakarta, 2010.

Bank Indonesia, "Laporan Sistem Pembayaran dan Pengedaran Uang 2010; Arah dan Kebijakan Sistem Pembayaran dalam Menyongsong Era Integrasi Ekonomi serta Upaya Meningkatkan Kualitas Uang dan Kehandalan Manajemen Pengelolaan Kas", Jakarta, 2011

Rehulina, "Multinational Corporations Sebagai Pengemban

Kewajiban dalam Hukum Hak Asasi Manusia." Training

Tingkat Lanjut Rule of Law dan Hak Asasi Manusia Bagi

Dosen Hukum dan HAM. Jakarta, 3-6 Juni 2015.

Siregar, Suci Yunita. "Penerapan Prinsip Non-Diskriminasi Pada Sistem Perdaganagn Multirlateral Dalam Kerangka WTO (World Trade Organization)". Skripsi Sarjana Hukum. Universitas Sumatera Utara, Medan, 2007.

Tim Inisiatif Bank Indonesia, "Upaya Meningkatkan Penggunaan Alat Pembayaran Non Tunai Melalui Pengembangan E-Money", Paper Work, Bank Indonesia, Jakarta, 2006.

\section{Laman}

Perusahaan Multinasional .https://id.m.wikipedia.org/wiki/

Perusahaan multinasional, diakses 13 Januari 2016, Pukul 06:18 WIB.

Mitsubishi, https://id.m.wikipedia.org/wiki/Mitsubishi, diakses 22 Maret 2016, Pukul 07:10 WIB.

Atur. http://kbbi.web.iid/atur, diakses 13 Januari 2016, Pukul 14:06 WIB. 